\title{
THICK FILM TEMPERATURE COMPENSATING CIRCUIT FOR SEMICONDUCTOR STRAIN GAUGES
}

\author{
HIDEO ARIMA, AKIRA IKEGAMI and HIROMI TOSAKI \\ Production Engineering Research Laboratory, Hitachi Ltd \\ MITSUO AI, YOSHITAKA MATSUOKA AND TSUTOMU OKAYAMA
}

Naka Works, Hitachi Ltd

\begin{abstract}
Thick film circuits were developed for temperature compensating of semiconductor strain gauges and for connecting the gauges to amplifiers in electronic pressure and differential pressure transmitters. In each circuit, ten Au pads for $\mathrm{Al}$ wire bonding and thirteen $\mathrm{Ag} / \mathrm{Pd}$ pads for soldering must be fabricated on a small substrate. The results of the research are shown below.

(1) The resistance values and the thermistor constants required for the thermistors are $0.9 \pm 0.09$ kilo-ohm and $2500 \pm 40$ Kelvin, respectively. Those characteristics are realized by developing a paste composition composed of a new spinel type oxide $\left(\mathrm{Mn}_{1.6} \mathrm{Co}_{0.8} \mathrm{Ni}_{0.35} \mathrm{Ru}_{0.25} \mathrm{O}_{4}\right), \mathrm{RuO}_{2}$ and glass.

(2) Accelerated life tests of the thick film thermistors reveal that the resistance drift rates of the thermistors are less than $\pm 0.02 \%$ /year at $120^{\circ} \mathrm{C}$.

(3) Life tests clarify that the wire bonding pads fabricated by using ESL 8882 Au paste keep more than 4 grams in pull strength, and that the soldering pads fabricated by using Sumitomo CLP $495 \mathrm{~A} \mathrm{Ag} / \mathrm{Pd}$ paste are more than 1 kilo-gram in pull strength.

(4) The temperature dependence of zero shift and span shift in the pressure transmitter are suppresed within $\pm 0.2 \%$ between $-40^{\circ} \mathrm{C}$ and $120^{\circ} \mathrm{C}$ by using the thick film circuit developed.
\end{abstract}

\section{INTRODUCTION}

Recently the semiconductor is being put into practice for electro-mechanical sensors making use of its small-size and high accuracy. In electronic pressure and differential pressure transmitters, semiconductor strain gauges are taking the place of thin metal strain gauges. The semiconductor strain gauges is sensitive to temperature as well as pressure. Thus temperature compensating elements, that is thermistors and resistors, are needed for preventing any temperature dependence of the out-put voltage. For (accurate) temperature compensation, the semiconductor strain gauges and thermistors must be assembled in the small pressure sensing part. A thick film thermistor is suitable for this assembly. The spinel type oxide- $\mathrm{RuO}_{2}$-glass ternary system was investigated for the thick film thermistors. ${ }^{1,2}$ So, we developed thick film circuits, in which three thick film thermistors for temperature compensating of strain gauges, ten $\mathrm{Al}$ wire bonding pads for connecting the strain gauges to the circuit, and thirteen soldering pads for connecting the circuit to an amplifier are fabricated. Each component must have high reliability for 20 years. It is required that the resistance drift rates of the thermistors are less than $\pm 0.3 \%$ /year at $120^{\circ} \mathrm{C}$, and that the pull strength values of the $\mathrm{Al}$ wire bonded pads and the soldered pads are more than $2 \mathrm{~g}$ and $500 \mathrm{~g}$, respectively after various stress conditions.

\section{MATERIALS AND EXPERIMENTAL PROCEDURE}

Semiconducting oxides, most of which are spinel type, were synthesized from reagent-grade $\mathrm{MnO}_{2}$, $\mathrm{CoO}, \mathrm{NiO}$ and $\mathrm{RuO}_{2}$ by the usual ceramic processes. The desired amounts of the oxides were mixed, calcined at $900^{\circ} \mathrm{C}$ for 2 hours, and ground. The resultant powder was pressed into disks, sintered at $1200^{\circ} \mathrm{C}$ for 2 hours, ground by wet-milling, and then dried. Mean diameters of the semiconducting oxides were about $2-3 \mu \mathrm{m}$.

The chemical composition of the glass binder used is shown in Table I. The glass binder was prepared by mixing the constituent oxides and carbonates, fusing at $1200^{\circ} \mathrm{C}$ for one hour in a $\mathrm{Pt}$ crucible, pouring into water, and wet-milling. The mean diameter of the glass 
used is about 7-8 $\mu \mathrm{m}$. The measured coefficient of linear expansion for glass is $79 \times 10^{-7} \mathrm{~K}^{-1}$ $\left(30-360^{\circ} \mathrm{C}\right)$.

TABLE I

Chemical composition of the glass binder.

\begin{tabular}{lllllll}
\hline \multicolumn{7}{c}{ Composition (wt\%) } \\
\hline $\mathrm{Pbo}$ & $\mathrm{SiO}_{2}$ & $\mathrm{~B}_{2} \mathrm{O}_{3}$ & $\mathrm{BaO}$ & $\mathrm{Na}_{2} \mathrm{O}$ & $\mathrm{Al}_{2} \mathrm{O}_{3}$ & $\mathrm{Bi}_{2} \mathrm{O}_{3}$ \\
\hline 8 & 39 & 6 & 28 & 6 & 5 & 8 \\
\hline
\end{tabular}

Thick film thermistor pastes were prepared by mixing the desired amount of semiconducting oxide, $\mathrm{RuO}_{2}$ and glass for 2 hours in an automatic mixing machine, and then kneading with an organic vehicle for 2 hours in the same mixing machine.

Electrical properties of thick film thermistors are highly dependent upon the particle sizes of the materials, especially $\mathrm{RuO}_{2}$. So, qualified $\mathrm{RuO}_{2}$ (the mean diameter is about $1 \mu \mathrm{m}$ ) was used in the paste fabrication process. A $9 \%$ ethylcellulose solution of tridecanol (or mixture of terpineol and ethyl carbitol acetate) was used as the organic vehicle.

Thick film thermistors were fabricated by the usual thick film processes. Thermistor paste was printed on a $96 \% \mathrm{Al}_{2} \mathrm{O}_{3}$ substrate with a prefired conductor pattern. Double printing was used in order to decrease the resistance of the thermistor. The thickness of the thermistor was about $40 \mu \mathrm{m}$ as-fired. The thick film thermistor was covered by a crystallizable glass, HG1030.

The electrical measurements were carried out using a digital voltmeter at $25.00 \pm 0.02^{\circ} \mathrm{C}$ and $-20.00+0.02^{\circ} \mathrm{C}$. The values of the thermistor constant $(B)$ were calculated using the following equation.

$$
\begin{aligned}
B & =\ln \left(R_{-20} / R_{25}\right)\left(T_{-20}^{-1}-T_{25}^{-1}\right)^{-1} \\
& =1675 \ln \left(R_{-20} / R_{25}\right)(\mathrm{K})
\end{aligned}
$$

where $R_{-20}$ : resistance value at $-20^{\circ} \mathrm{C}$

$R_{25}$ : resistance value at $25^{\circ} \mathrm{C}$

$T_{-20}: 253 \mathrm{~K}, \quad \mathrm{~T}_{25}: 298 \mathrm{~K}$

In order to evaluate the stability of the semi-conducting oxide, we determined "Stability" in the following way. The samples of semiconducting oxide were heated from $300^{\circ} \mathrm{C}$ to $600^{\circ} \mathrm{C}$ and cooled from $600^{\circ} \mathrm{C}$ to $300^{\circ} \mathrm{C}$ at $100^{\circ} \mathrm{C}$ intervals in order. The samples were held at each temperature for one hour, after which they were quenched to room temperature, and the resistance was measured at $25^{\circ} \mathrm{C}$. Regarding
$R_{\max }$ and $R_{\min }$ as the maximum and minimum values in measured resistance,"Stability" was defined as $\log \left(R_{\max } / R_{\min }\right)$.

\section{RESULTS}

\subsection{Thick Film Circuit Design}

Figure 1 shows a bridge circuit of the strain gauge developed for a pressure transmitter. $R_{1}-R_{4}$ and $R_{G}$ are piezo-resistors (= semiconductor strain gauges) fabricated on a single crystal silicon diaphragm. $R_{x}$ and $R_{y}$ are temperature compensating composite resistors for zero output and for span, respectively. Both are composed of the same elements.

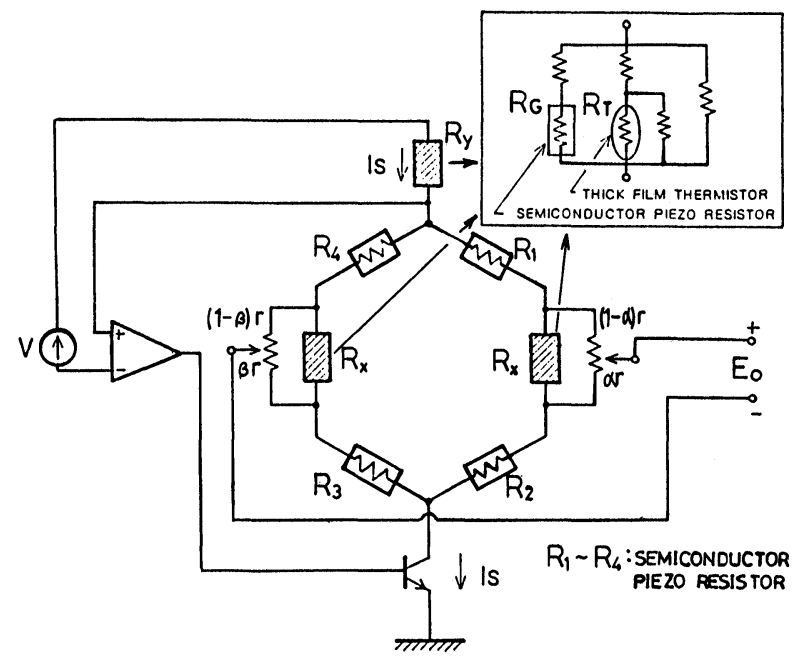

FIGURE 1 Bridge circuit of the strain gauge.

The output voltage $E_{0}$ of the bridge is given as

$$
E_{0}=\left(\Delta R+\frac{\alpha-\beta}{2} R_{z}\right) I_{s}
$$

where $R_{z}=r R_{x} /\left(R_{x}+r\right), I_{s}$ is current through the bridge and $\Delta R$ is the resistance variation of a piezoresistor caused by stress.

The partially differentiated form of Eq. (2) with respect to temperature $(T)$ is as follows:

$$
\begin{aligned}
\frac{\partial E_{0}}{\partial T}=\left(I_{s} \frac{\partial \Delta R}{\partial T}+\Delta R\right. & \left.\frac{\partial I_{s}}{\partial T}\right) \\
& +\frac{\alpha-\beta}{2}\left(I_{s} \frac{\partial R_{z}}{\partial T}+R_{z} \frac{\partial I_{s}}{\partial T}\right)
\end{aligned}
$$


The null condition on the temperature dependence of $E_{0}$, regardless of the value of $\alpha$ and $\beta$, will be derived from the Eq. (2) as

$$
\frac{1}{\Delta R} \frac{\partial \Delta R}{\partial T}=\frac{1}{R_{z}} \frac{\partial R_{z}}{\partial T}=-\frac{1}{I_{s}} \frac{\partial I_{s}}{\partial T}
$$

Therefore, the relationship between $R_{y}, R_{z}$ and $\Delta R$ is described as follows.

$$
R_{y}(T)=C_{1} R_{z}(T)=C_{2} \Delta R(T){ }_{\left(C_{1}, C_{2}: \text { constant }\right)}
$$

In order to satisfy Eq. (4), $R_{y}$ and $R_{z}$ are composed of the piezo-resistor $\left(R_{G}\right)$ with a positive temperature coefficient, the thermistor $\left(R_{T}\right)$ with a negative temperature coefficient, and resistors.

Table II shows some examples of the calculated temperature dependence of output voltage for various thermistor constants using the nonlinear least squares method. It is clear that the higher the thermistor constant becomes the larger the error is at low temperatures. The circuit containing the thermistor with a high thermistor constant, however, has the capacity to compensate for large impedance variations in the piezo-resistors. As a result, it becomes clear after the investigation that the optimum thermistor constant and resistance of the thermistor at $25^{\circ} \mathrm{C}$ are $2500 \pm 40 \mathrm{~K}$ and $0.9 \pm 0.09 \mathrm{k} \Omega$, respectively. The variations of the characteristics are limited by the requirement for accuracy in the thermistors.

TABLE II

Calculated maximum errors and capacity of compensation for various thermistor const.

\begin{tabular}{lllll}
\hline & $\begin{array}{l}\text { Thermistor } \\
\text { const. (K) }\end{array}$ & \multicolumn{2}{l}{ Maximum error (\%) } & \\
\cline { 3 - 4 } No. & $-40^{\circ} \mathrm{C}$ & $120^{\circ} \mathrm{C}$ & $\begin{array}{l}\text { Capacity of } \\
\text { compensation }\end{array}$ \\
\hline 1 & 2000 & -0.08 & +0.12 & poor \\
2 & 2500 & -0.15 & +0.07 & good \\
3 & 3000 & -0.40 & +0.03 & excellent \\
\hline
\end{tabular}

\subsection{Thick Film Thermistor}

3.2.1 Semiconducting oxide materials. Because of its stability and the variety of its characteristics, $(\mathrm{Mn}, \mathrm{Co}, \mathrm{Ni})_{3} \mathrm{O}_{4}$ spinel type oxide is the most popular semiconducting oxide material for thermistors. ${ }^{3}$ Figures 2-4 show the characteristics of the spinel oxide; that is, the coefficient of linear

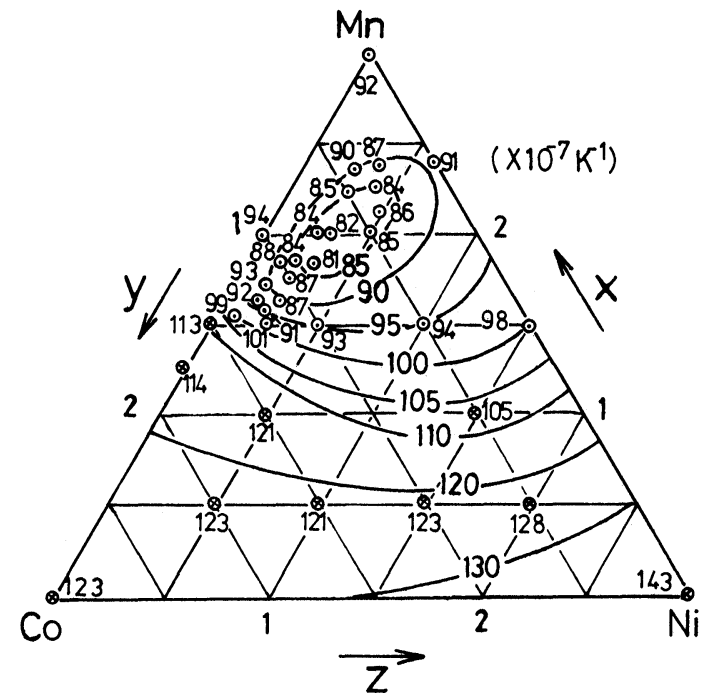

FIGURE 2 Coefficient of linear expansion in the system of $(\mathrm{Mn}, \mathrm{Co}, \mathrm{Ni})_{3} \mathrm{O}_{4}$.

expansion, the resistivity and the thermistor constant. Among these characteristics, the coefficient of linear expansion is the most important factor for thick film thermistors composed of semiconducting oxide, $\mathrm{RuO}_{2}$ and glass. It is revealed that the coefficient of linear expansion of the semiconducting oxide must be less than $105 \times 10^{-7} \mathrm{~K}^{-1}$, otherwise micro-cracks are inevitable in the thick film thermistor. Micro-cracks in the film incur large resistance drift in the thermistor

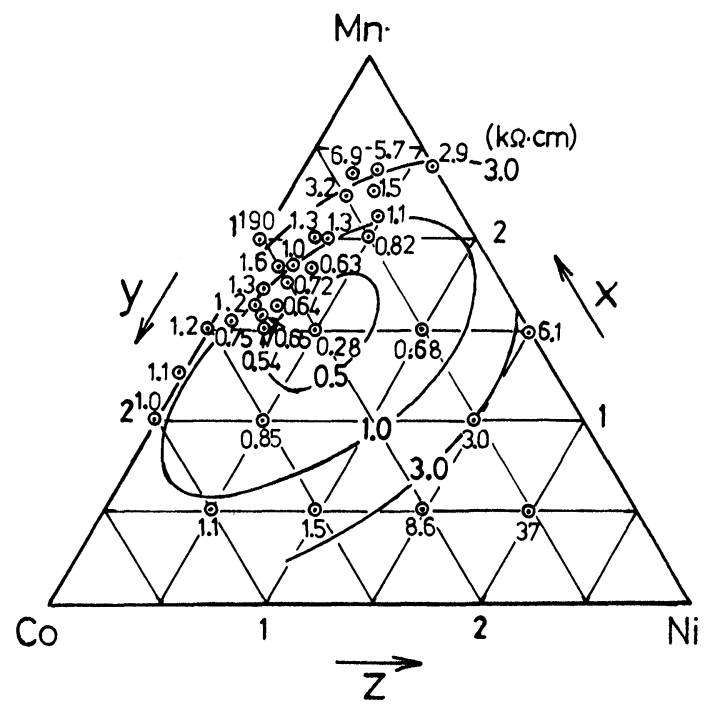

FIGURE 3 Resistivity in the $(\mathrm{Mn}, \mathrm{Co}, \mathrm{Ni})_{3} \mathrm{O}_{4}$ system. 


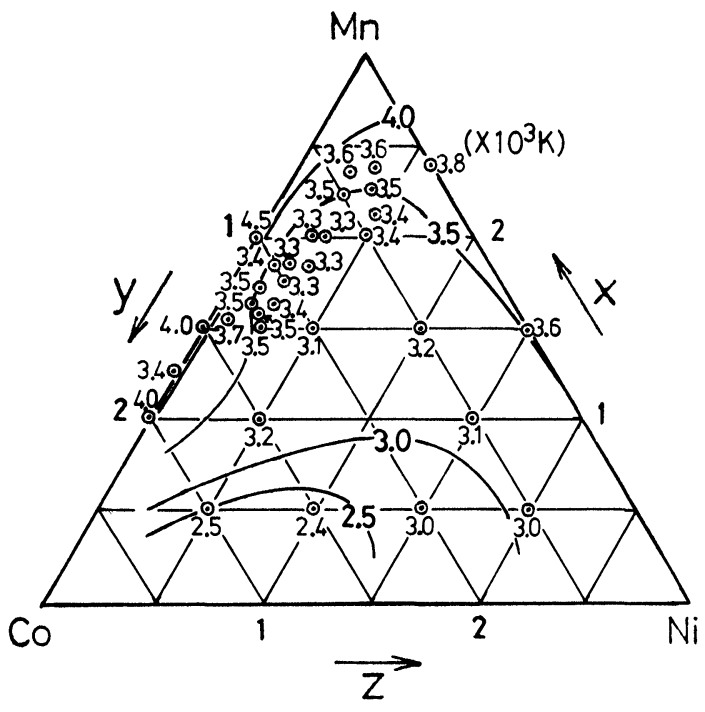

FIGURE 4 Thermistor constant in the system of (Mn, Co, $\mathrm{Ni})_{3} \mathrm{O}_{4}$

following environmental tests, such as the thermal shock test. The distribution of the composition whose coefficient of linear expansion is less than $105 \times 10^{-7}$ $\mathrm{K}^{-1}$ is localized in the $\mathrm{Mn}$ rich region. In this region, however, the resistivity is too large to fabricate the $0.9 \mathrm{k} \Omega$ thermistor and the thermistor constant is too high to realize a $2500 \mathrm{~K}$ thermistor. It is well known that compounds containing $\mathrm{Ru}^{4+}$, e.g., $\mathrm{CaRuO}_{3}$, $\mathrm{SrRuO}_{3}, \mathrm{~Pb}_{2} \mathrm{Ru}_{2} \mathrm{O}_{7-x}, \mathrm{Bi}_{2} \mathrm{Ru}_{2} \mathrm{O}_{7-x}$ and $\mathrm{Lu}_{2} \mathrm{Ru}_{2} \mathrm{O}_{7}$, have both a low resistivity and a low thermistor constant. $^{4-7}$ So, we examined a solid solution of the system of $(\mathrm{Mn}, \mathrm{Co}, \mathrm{Ni})_{3} \mathrm{O}_{4}-\mathrm{RuO}_{2}$.

Figure 5 shows the resistivity, thermistor constant, coefficient of linear expansion and lattice constant as functions of the $\mathrm{RuO}_{2}$ content in the system of $(1-x / 3) \mathrm{Mn}_{2} \mathrm{Co}_{0.5} \mathrm{Ni}_{0.5} \mathrm{O}_{4}-x \mathrm{RuO}$. Resistivity increases slightly with increasing $x$ to a peak, followed by a large reduction. The thermistor constant decreases rather steadily as $x$ increases. The coefficient of linear expansion has a maximum value at $x=0.6$. The lattice constant of spinel increases as $x$ increases. Further investigations clarified that a single spinel type compound is synthesized at $x<0.6$ and that a mixture compound of spinel type oxide and $\mathrm{RuO}_{2}$ exists with $x \geqq 0.6$ as shown in Figure 6 .

Table III shows the characteristics of the compound in the system of ( $\mathrm{Mn}, \mathrm{Co}, \mathrm{Ni}, \mathrm{Ru})_{3} \mathrm{O}_{4}$, whose coefficients of linear expansion are smaller than $105 \times$ $10^{-7} \mathrm{~K}^{-1}$. In the compound in Table III, the composition $\mathrm{Mn}_{1.6} \mathrm{Co}_{0.8} \mathrm{Ni}_{0.35} \mathrm{Ru}_{0.25} \mathrm{O}_{4}$ is found to be the most

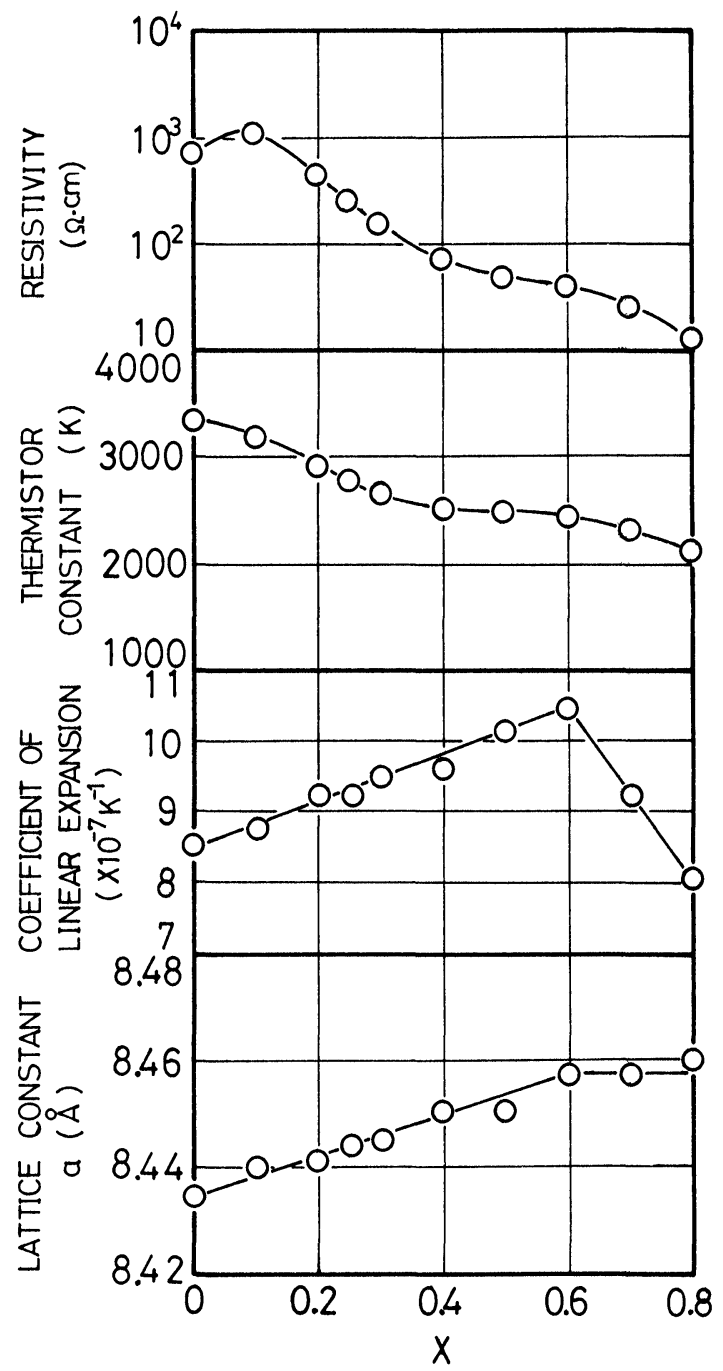

FIGURE 5 Characteristics of the system $(1-x / 3) \mathrm{Mn}_{2} \mathrm{Co}_{0.5} \mathrm{Ni}_{0.5} \mathrm{O}_{4}-x \mathrm{RuO}_{2}$.

suitable for the thermistor in regard to the resistivity, thermistor constant, and stability required.

3.2.2 Thermistor paste materials. Figure 7 shows the effect of the addition of $\mathrm{RuO}_{2}$ on the resistivity and the thermistor constant of the $\mathrm{Mn}_{1.6} \mathrm{Co}_{0.8} \mathrm{Ni}_{0.35} \mathrm{Ru}_{0.25} \mathrm{O}_{4}-$ $\mathrm{RuO}_{2}$-glass system with a $40 \mathrm{wt} \%$ glass content. The thermistor constant remains almost unchanged when the weight of $\mathrm{RuO}_{2}$ is increased up to $10 \mathrm{wt} \%$ whereas the resistivity changes from $500 \mathrm{k} \Omega / \square$ to $50 \mathrm{k} \Omega / \square$ in this range. A thermistor constant of $2500 \mathrm{~K}$ is realized for the composition $\mathrm{Mn}_{1.6} \mathrm{Co}_{0.8} \mathrm{Ni}_{0.35} \mathrm{Ru}_{0.25} \mathrm{O}_{4}: 50 \mathrm{wt} \%$, 


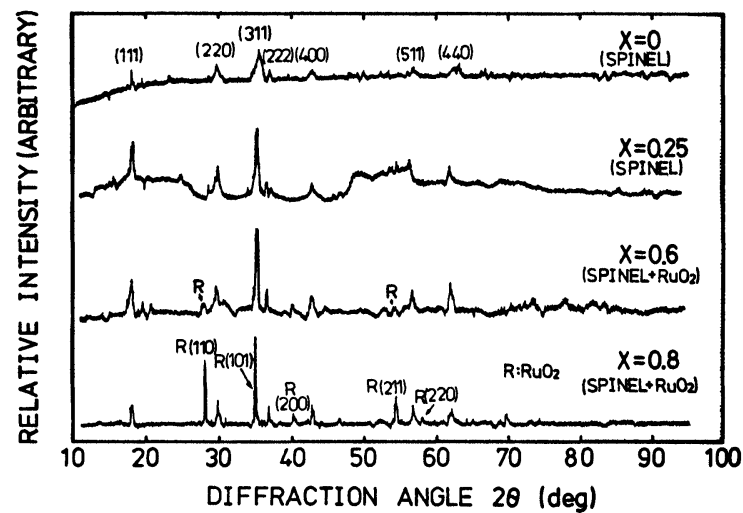

FIGURE 6 Variation of X-ray diffraction pattern of the system $(1-x / 3) \mathrm{Mn}_{2} \mathrm{Co}_{0.5} \mathrm{Ni}_{0.5} \mathrm{O}_{4}-x \mathrm{RuO}_{2}$.

$\mathrm{RuO}_{2}: 10 \mathrm{wt} \%$, and glass: $40 \mathrm{wt} \%$, where sheet resistivity is $50 \mathrm{k} \Omega / \square$.

Figure 8 shows the firing temperature dependence of the sheet resistivity and the thermistor constant in the thick film thermistor. In this composition, the resistivity and thermistor constant are stable in the firing temperature range of $850-900^{\circ} \mathrm{C}$.

\subsubsection{Thick film thermistor. Figure 9 shows a} configuration of the thick film thermistor developed for temperature compensation of semiconductor strain gauges. The electrode is of a comb type, having two extended teeth which can be cut for resistance adjustment. In these thermistors, whose resistance

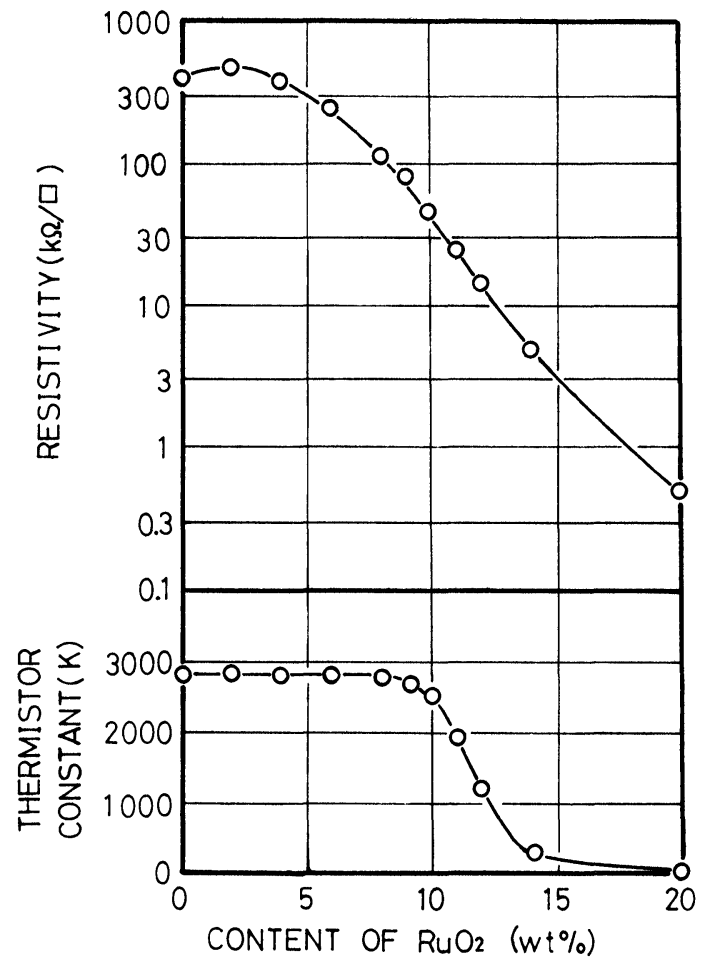

FIGURE 7 Effects of $\mathrm{RuO}_{2}$ addition on the resistivity and thermistor constant of the $\mathrm{Mn}_{1.6} \mathrm{Co}_{0.8} \mathrm{Ni}_{0.35} \mathrm{Ru}_{0.25} \mathrm{O}_{4}-\mathrm{RuO}_{2}$ - glass system (Glass content:40 wt\%, Firing temperature: $\left.900^{\circ} \mathrm{C}\right)$

TABLE III

Characteristics of the compounds in the system of $(\mathrm{Mn}, \mathrm{Co}, \mathrm{Ni}, \mathrm{Ru})_{3} \mathrm{O}_{4}$

\begin{tabular}{rllllll}
\hline No. & Composition & $\begin{array}{l}\text { Coefficient of } \\
\text { linear expansion } \\
\left(\times 10^{-7} \mathrm{~K}^{-1}\right)\end{array}$ & $\begin{array}{l}\text { Resistivity } \\
\left(\text { at } 25^{\circ} \mathrm{C}\right) \\
(\Omega \cdot \mathrm{cm})\end{array}$ & $\begin{array}{l}\text { Thermistor } \\
\text { constant } \\
(\mathrm{K})\end{array}$ & $\begin{array}{l}\text { Stability } \\
(300-600 \\
\left.-300^{\circ} \mathrm{C}\right)\end{array}$ & Crystal structure \\
\hline 1 & $\mathrm{Mn}_{1.87} \mathrm{Co}_{0.47} \mathrm{Ni}_{0.47} \mathrm{Ru}_{0.2} \mathrm{O}_{4}$ & 92 & 440 & 2900 & - & Spinel \\
2 & $\mathrm{Mn}_{1.83} \mathrm{Co}_{0.46} \mathrm{Ni}_{0.46} \mathrm{Ru}_{0.25} \mathrm{O}_{4}$ & 92 & 260 & 2750 & - & Spinel \\
3 & $\mathrm{Mn}_{1.8} \mathrm{Co}_{0.45} \mathrm{Ni}_{0.45} \mathrm{Ru}_{0.3} \mathrm{O}_{4}$ & 99 & 71 & 2350 & 0.07 & Spinel \\
4 & $\mathrm{Mn}_{1.6} \mathrm{Co}_{0.8} \mathrm{Ni}_{0.35} \mathrm{Ru}_{0.25} \mathrm{O}_{4}$ & 98 & 51 & 2700 & 0.02 & Spinel \\
5 & $\mathrm{Mn}_{1.58} \mathrm{Co}_{0.79} \mathrm{Ni}_{0.34} \mathrm{Ru}_{0.3} \mathrm{O}_{4}$ & 99 & 27 & 2500 & 0.04 & - \\
6 & $\mathrm{Mn}_{1.62} \mathrm{Co}_{1.08} \mathrm{Ru}_{0.3} \mathrm{O}_{4}$ & 97 & 17 & 2100 & 0.09 & - \\
7 & $\mathrm{Mn}_{1.5} \mathrm{Co}_{0.5} \mathrm{Ni}_{0.75} \mathrm{Ru}_{0.25} \mathrm{O}_{4}$ & 98 & 44 & 2480 & 0.03 & Spinel \\
8 & $\mathrm{Mn}_{1.5} \mathrm{Co}_{0.25} \mathrm{Ni}_{0.88} \mathrm{Ru}_{0.38} \mathrm{O}_{4}$ & 97 & 30 & 2290 & 0.07 & - \\
9 & $\mathrm{Mn}_{1.5} \mathrm{NIRU}_{0.5} \mathrm{O}_{4}$ & 96 & 28 & 2310 & 0.17 & Spinel \\
10 & $\mathrm{Mn}_{1.75} \mathrm{Co}_{0.75} \mathrm{Ru}_{0.5} \mathrm{O}_{4}$ & 96 & 278 & 2400 & - & - \\
11 & $\mathrm{Mn}_{1.6} \mathrm{CoRu}_{0.4} \mathrm{O}_{4}$ & 88 & 97 & 2200 & 0.08 & - \\
12 & $\mathrm{Mn}_{1.5} \mathrm{Co}_{1.1} \mathrm{Ru}_{0.4} \mathrm{O}_{4}$ & 97 & 2000 & 0.04 & Spinel + Hausmannite \\
13 & $\mathrm{Mn}_{1.5} \mathrm{Co}_{1.25} \mathrm{Ru}_{0.25} \mathrm{O}_{4}$ & 98 & 31 & 2500 & 0.13 & Spinel + Hausmannite \\
\hline
\end{tabular}




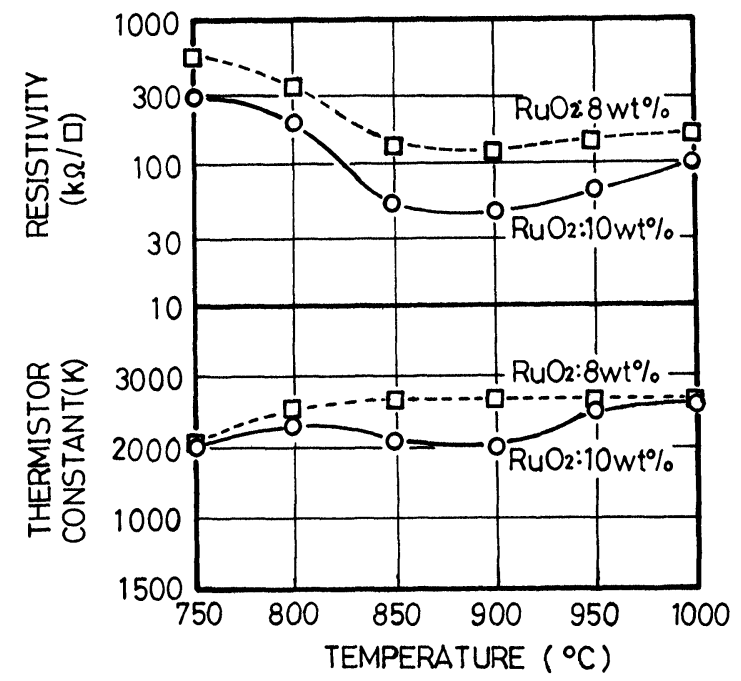

FIGURE 8 Firing temperature dependence of sheet resistivity and thermistor constant in the thick film thermistor

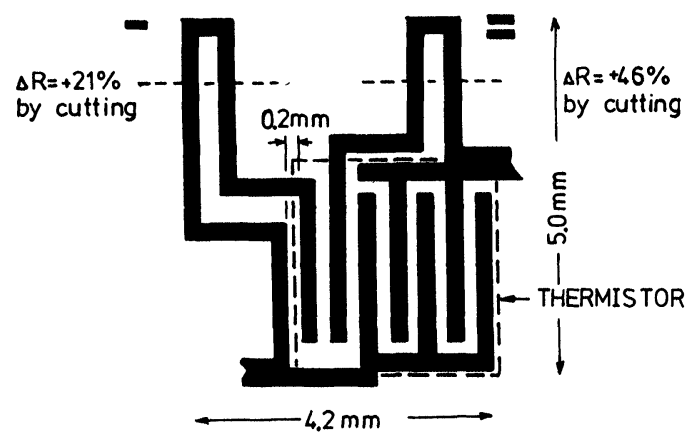

FIGURE 9 Comb type electrode configuration of the thick film thermistor

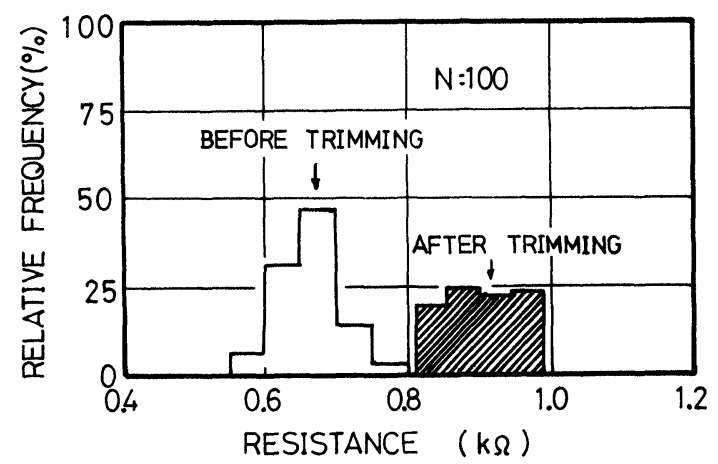

FIGURE 10 Distribution chart of resistance at $25^{\circ} \mathrm{C}$. variation is about $\pm 30 \%$, resistance of almost $0.9 \pm 0.09 \mathrm{k} \Omega$ can be attained, if necessary, by cutting one of the extended teeth of the electrode.

Figure 10 shows a distribution of the resistance before and after trimming. All resistance values for the thermistors meet the requirement of $R=0.9 \pm 0.09 \mathrm{k} \Omega$ by trimming.

Figure 11 shows the distribution of the thermistor constant. The variation of the thermistor constant is $2500 \pm 30 \mathrm{~K}$, which satisfies the requirement.

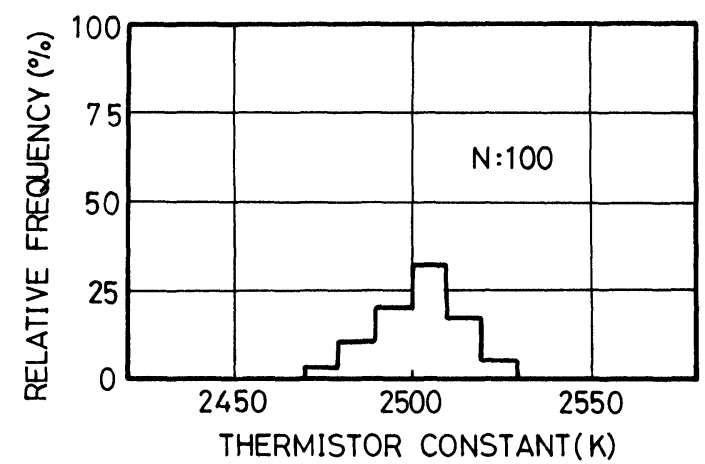

FIGURE 11 Distribution chart for thermistor constant

3.2.4 Reliability of the thermistor. Figure 12 shows the resistance changes of as-fired thick film thermistors at $100^{\circ} \mathrm{C}$ as a parameter of the firing temperature. The rate of resistance change varies with firing temperature. It is revealed that the rate of the resistance change takes minimum values at $900^{\circ} \mathrm{C}$, which is the optimum firing temperature.

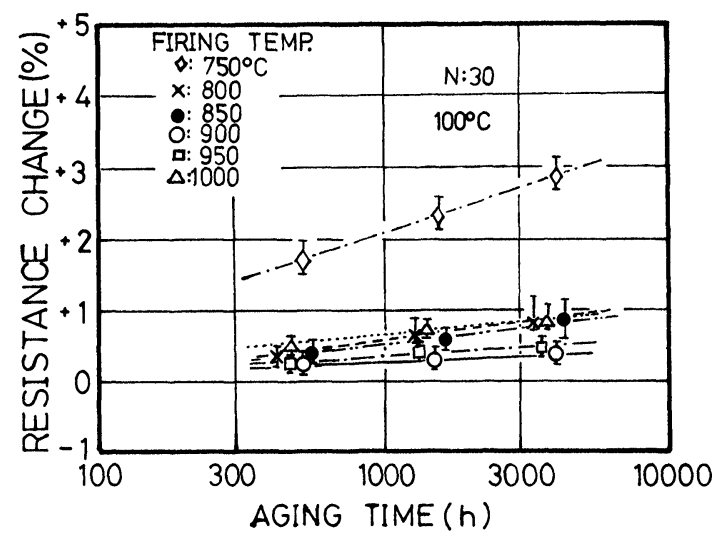

FIGURE 12 Effect of firing temperature on the stability of as-fired thick film thermistors

Figure 13 shows the resistance change of the glass coated thick film thermistors at various incubation 


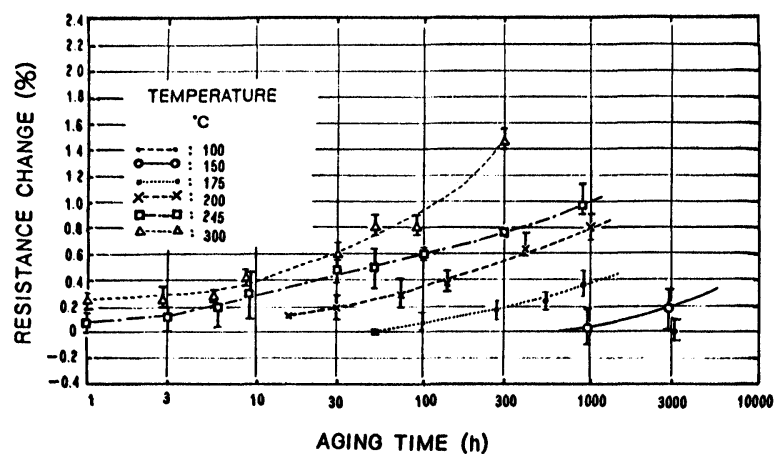

FIGURE 13 Resistance change of glass-coated thick film thermistor at high temperatures

temperatures. The resistance drift rate of the thick film thermistor increases with increasing incubation temperature. As an indicator of the resistance drift rate of thick film thermistors, the times for resistance change to rise to $0.1,0.2$ and $0.3 \%$ have been plotted against reciprocal temperature in Figure 14. This figure

$T\left({ }^{\circ} \mathrm{C}\right)$

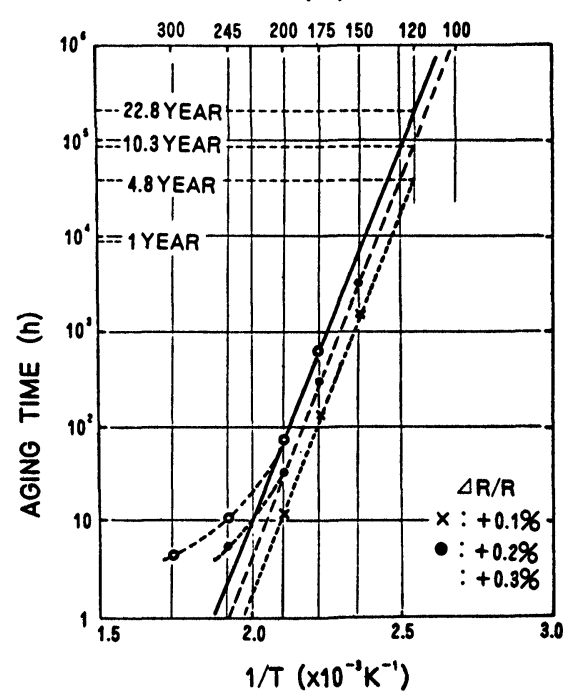

FIGURE 14 Time-temperature equivalence plot indicates that the relationship between reciprocal temperature and the times to reach prescribed resistance change follows Arrhenius's equation, and the aging mechanism is the same as at temperatures below $200^{\circ} \mathrm{C}$.

Assuming the Arrhenius behaviour, the resistance drift rate at the lower temperatures can be predicted. The thick film thermistor has such a high stability that it takes $4.8,10.3$ and 22.8 years for the resistance change to reach $0.1,0.2$ and $0.3 \%$ at $120^{\circ} \mathrm{C}$, respectively.

Typical stability data under various stress conditions are shown in Table IV.

\subsection{Wire Bonding Pad}

Several Au pastes on the market were investigated to be used in connection with the $\mathrm{Al}$ wire bonding pads under various stress conditions.

Figure 15 shows an example of the change in bond strength as a function of time.

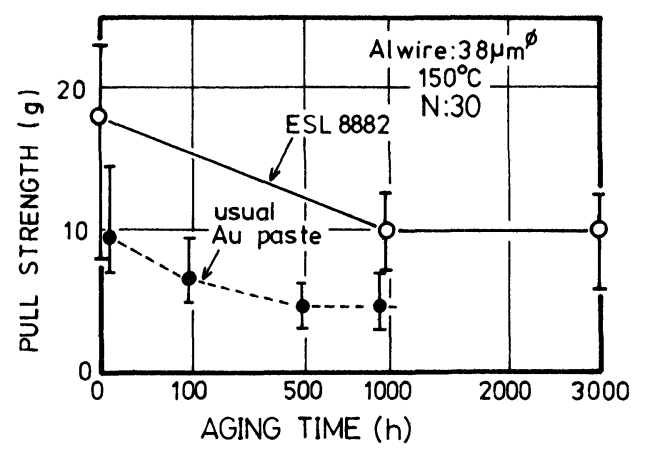

FIGURE 15 Bond strength as a function of storage time

Figure 16 shows the change in contact resistance between the $\mathrm{Au}$ pad and the bonded $\mathrm{Al}$ wire. It was revealed that the usual contact resistance between the $\mathrm{Au}$ pad and the bonded $\mathrm{Al}$ wire increased rapidly with increasing storage time, due to the creation of intermetallic compounds.

TABLE IV

Stability of the thick film thermistor under various stress conditions.

\begin{tabular}{lllll}
\hline No. & Test & Stress condition & Time or cycle & Resistance change \\
\hline 1 & High temp. storage test & $150^{\circ} \mathrm{C}$ & $3000 \mathrm{~h}$ & $+0.20 \%\left(-0.07^{\circ} \mathrm{C}\right)$ \\
2 & High temp. load test & $150^{\circ} \mathrm{C}, 10 \mathrm{~m} \mathrm{Adc}$ & $1200 \mathrm{~h}$ & $+0.14 \%\left(-0.05^{\circ} \mathrm{C}\right)$ \\
3 & High temp. humidity load test & $60^{\circ} \mathrm{C}, 95 \% \mathrm{RH}, 0.3 \mathrm{~m} \mathrm{Adc}$ & $1200 \mathrm{~h}$ & $+0.02 \%\left(-0.007^{\circ} \mathrm{C}\right)$ \\
4 & Thermal shock test & $30 \mathrm{~min}$ at $-55^{\circ} \mathrm{C}$ and & 1200 cycles & $+0.03 \%\left(-0.011^{\circ} \mathrm{C}\right)$ \\
& & & \\
\hline
\end{tabular}

( ): Temperature change corresponding to the resistance change. 


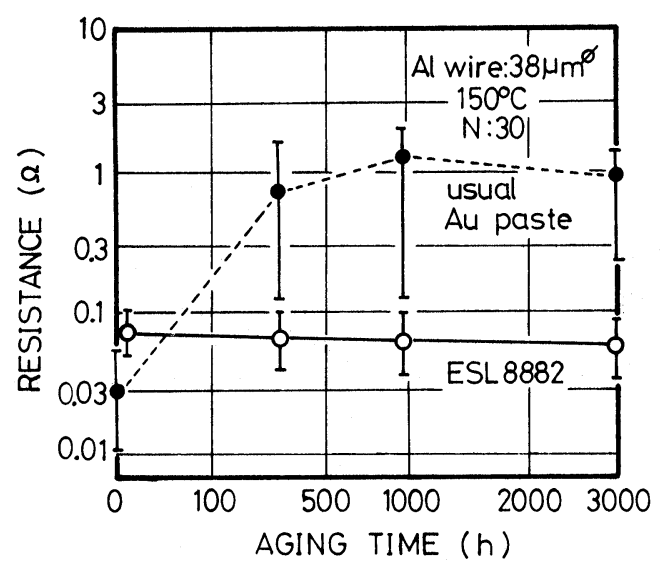

FIGURE 16 Change in contact resistance between Au pad and bonded $\mathrm{Al}$ wire

Of the three pastes, Du Pont 9910, Engelhard 2859, and ESL 8882, ESL 8882 was found to be the most suitable paste for the pad material, with regard to contact resistance drift and printability. The bonding pad fabricated by using ESL 8882 retains more than $4 \mathrm{~g}$ in pull strength under various environmental tests.

\subsection{Soldering Pad}

$\mathrm{Ag} / \mathrm{Pd}, \mathrm{Ag} / \mathrm{Pt}, \mathrm{Au} / \mathrm{Pt}$ and $\mathrm{Cu}$ pastes were examined for the soldering pad.

Figure 17 shows the average peel strength as a function of storage time at $150^{\circ} \mathrm{C}$. Degradation in peel strength was observed in all samples. The strength of the pads fabricated by Sumitomo CLP 495A and Du Pont 9061, however, stabilized at certain values. An

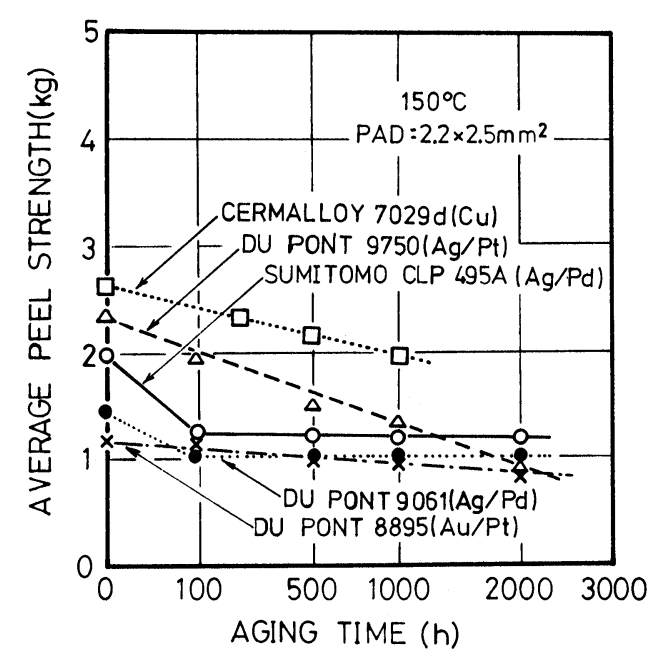

FIGURE 17 Average peel strength as a function of aging time. average peel strength of $1.2 \mathrm{~kg}$ was attained with CLP 495A.

Ring shape soldering pads were fabricated with CLP 495A, on which $\mathrm{Cr} / \mathrm{Cu} / \mathrm{Au}$ sputtered thin films were deposited. The pull strength of the pads whose inside and outside diameters were $0.5 \mathrm{~mm}$ and $1.0 \mathrm{~mm}$, respectively, is more than $1 \mathrm{~kg}$ under various stress conditions.

\subsection{Thick Film Circuit}

Figure 18 shows a typical flow chart of the production process for a thick film circuit for temperature compensation of strain gauges.

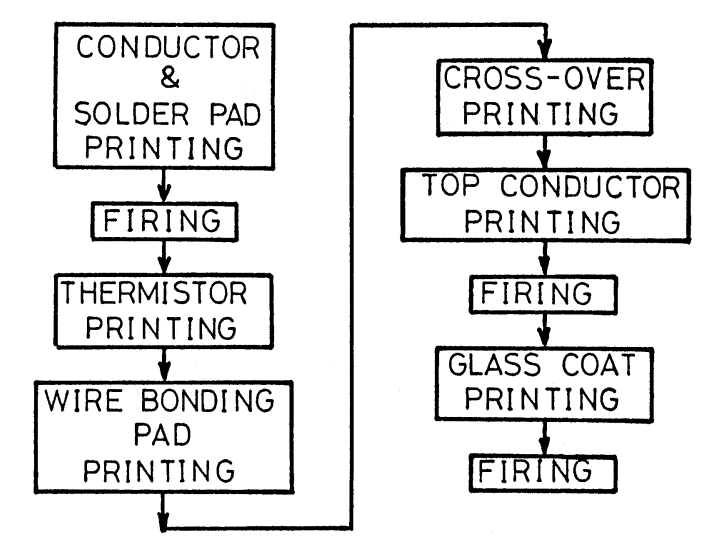

FIGURE 18 Typical production process of thick film circuit for temperature compensation of strain gauges

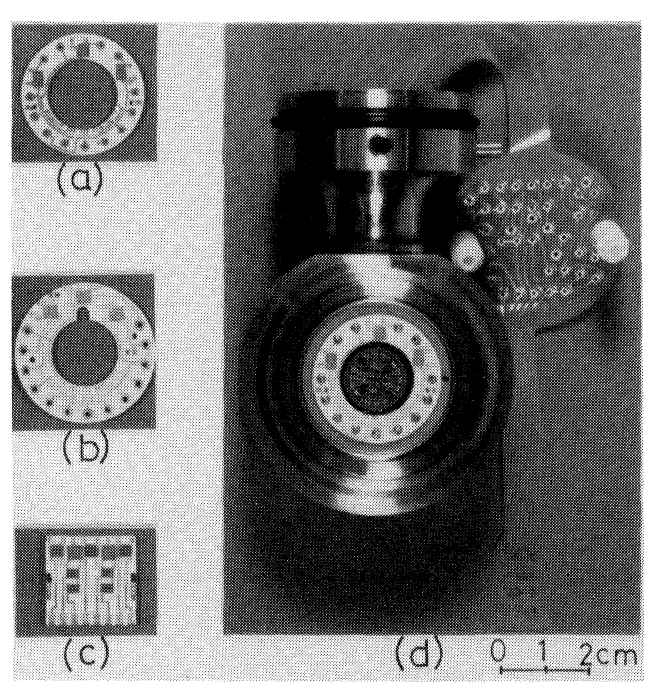

FIGURE 19 Thick film circuits and a pressure sensing part of a transmitter (a), (b): Thick film circuits for pressure transmitter (c): Thick film circuit for differential pressure transmitter. 
Figure 19 shows some types of fabricated thick film circuits $(a, b, c)$ and a pressure sensing part $(d)$, in which semiconductor strain gauges and thick film circuits are assembled. In Figure 19(d), the black circular part in the centre is a single crystal silicon diaphragm on which semiconductor strain gauges are formed, and the three gray-coloured rectangles on the thick film circuit are thick film thermistors.

Figure 20 shows errors of zero and span after temperature compensation. The errors are less than $\pm 0.2 \%$, whereas the maximum errors before temperature compensation were several per cent. Drastic decreases in the errors are realized using the thick film circuit.

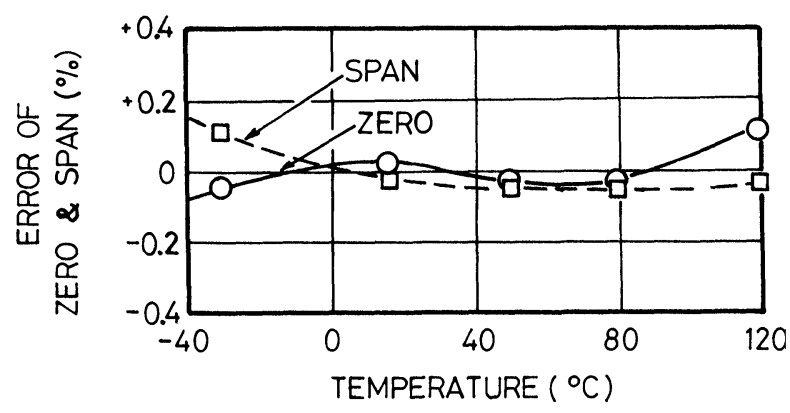

FIGURE 20 Errors of zero and span after temperature compensation (maximum errors before compensation were $5-6 \%)$

\section{CONCLUSION}

Thick film circuits, each of which is composed of thick film thermistors, Al wire bonding pads and soldering pads have been described. It has been proved through this research that the new thick film thermistors composed of the spinel type oxide $\left(\mathrm{Mn}_{1.6} \mathrm{Co}_{0.8} \mathrm{Ni}_{0.35} \mathrm{Ru}_{0.25} \mathrm{O}_{4}\right), \mathrm{RuO}_{2}$ and glass are suitable for temperature compensating of semiconductor strain gauges in electronic pressure and differential pressure transmitters. It also has been clarified that the wire bonding pads fabricated by using ESL $8882 \mathrm{Au}$ paste and the soldering pads fabricated by using Sumitomo CLP 495A Ag/Pd paste have high reliabilities under various stress conditions, and are suitable for temperature compensating circuits of transmitters.

\section{REFERENCES}

1. A. Ikegami, H. Tosaki, T. Mozume et al., "Spinel-precious metal-glass thick film thermistor paste", 287 in Proc. 1976 Int. Microelectronic Symp.

2. H. Arima, A. Ikegami, H. Tosaki et al., "Microstructures and their relation to electrical properties of spinel type oxide $-\mathrm{RuO}_{2}-$ glass thick film thermistor", B67 in Collected Abstracts of International Conference on Solid Films and Surfaces, (1978).

3. I. T. Sheflel, A. I. Zaslavskii et al., "Electrical properties and structure of complex oxide semiconductors, II, $\mathrm{MnO}-\mathrm{CoO}-\mathrm{NiO}-\mathrm{O}_{2}$ and $\mathrm{MnO}-\mathrm{CuO}-\mathrm{NiO}-\mathrm{O}_{2}$ system", 1979-1995 Soviet Physics Solid State, 3, (1962).

4. J. M. Longo, P. M. Raccah and J. B. Goodenough, " $\mathrm{Pb}_{2} \mathrm{M}_{2} \mathrm{O}_{\mathrm{t}-\mathrm{x}}(\mathrm{M}: \mathrm{Ru}, \mathrm{Ir}, \mathrm{Re})$ - preparation and properties of oxygen deficient pyrochlores", 191-202 Material Research Bulltin, 4 (1969).

5. A. W. Sleight and R. J. Bouchard, "Precious metal pyrochlores" 227-232, National Bureau of Standards Special Publication 364, Solid Chemistry, Proceedings of 5th Material Research Symposium, July (1972).

6. R. J. Bouchard and J. L. Gillson, "A new family of bismuth-precious metal pyrochlores", 669-680 Material Research Bulltein 6, (1972).

7. Paul R. Van Loan, "Conductive ternary oxides of ruthenium, and their use in thick film resistor glazes", 231-233 Ceramic Bulletin, 51, 3, (1972). 

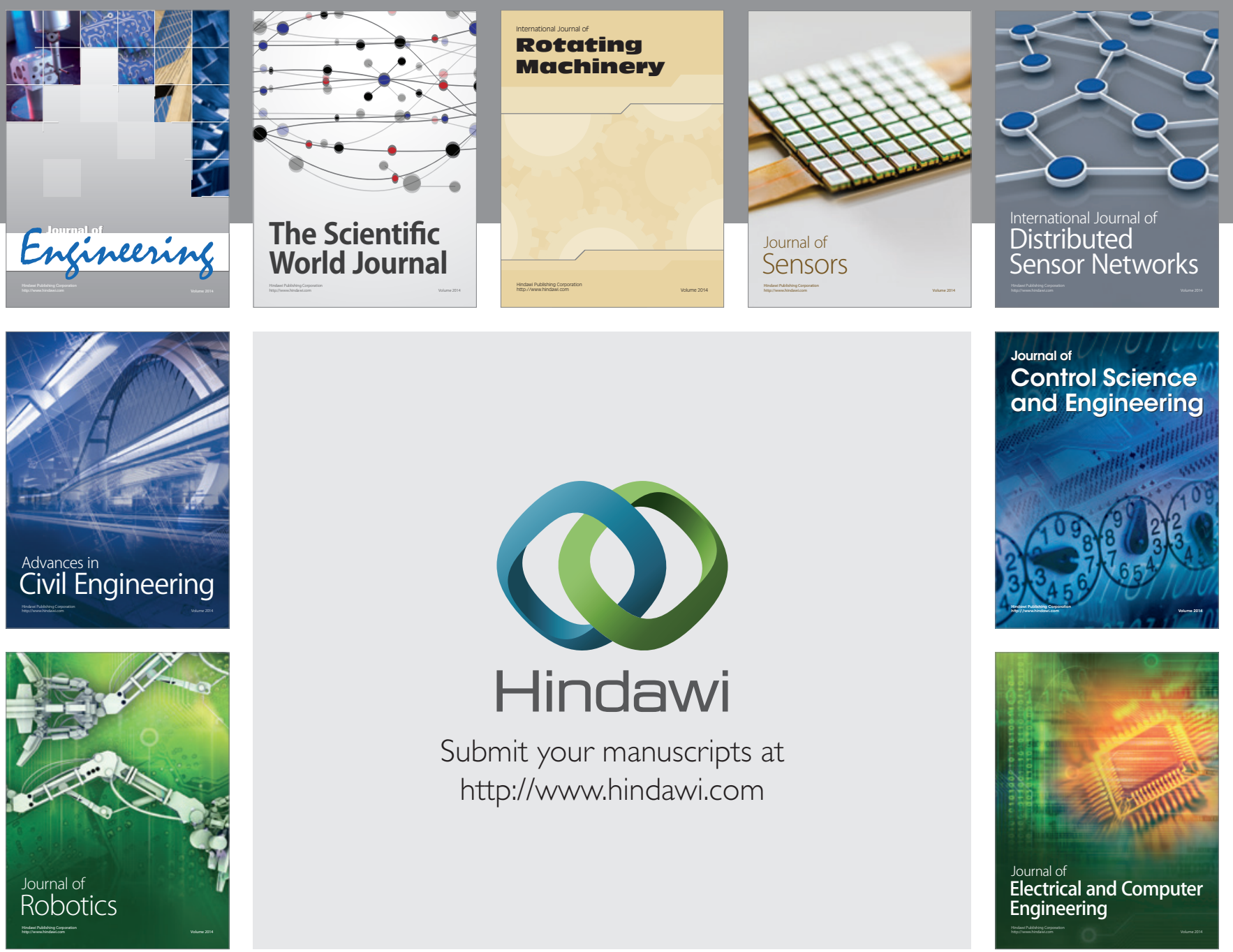

Submit your manuscripts at

http://www.hindawi.com
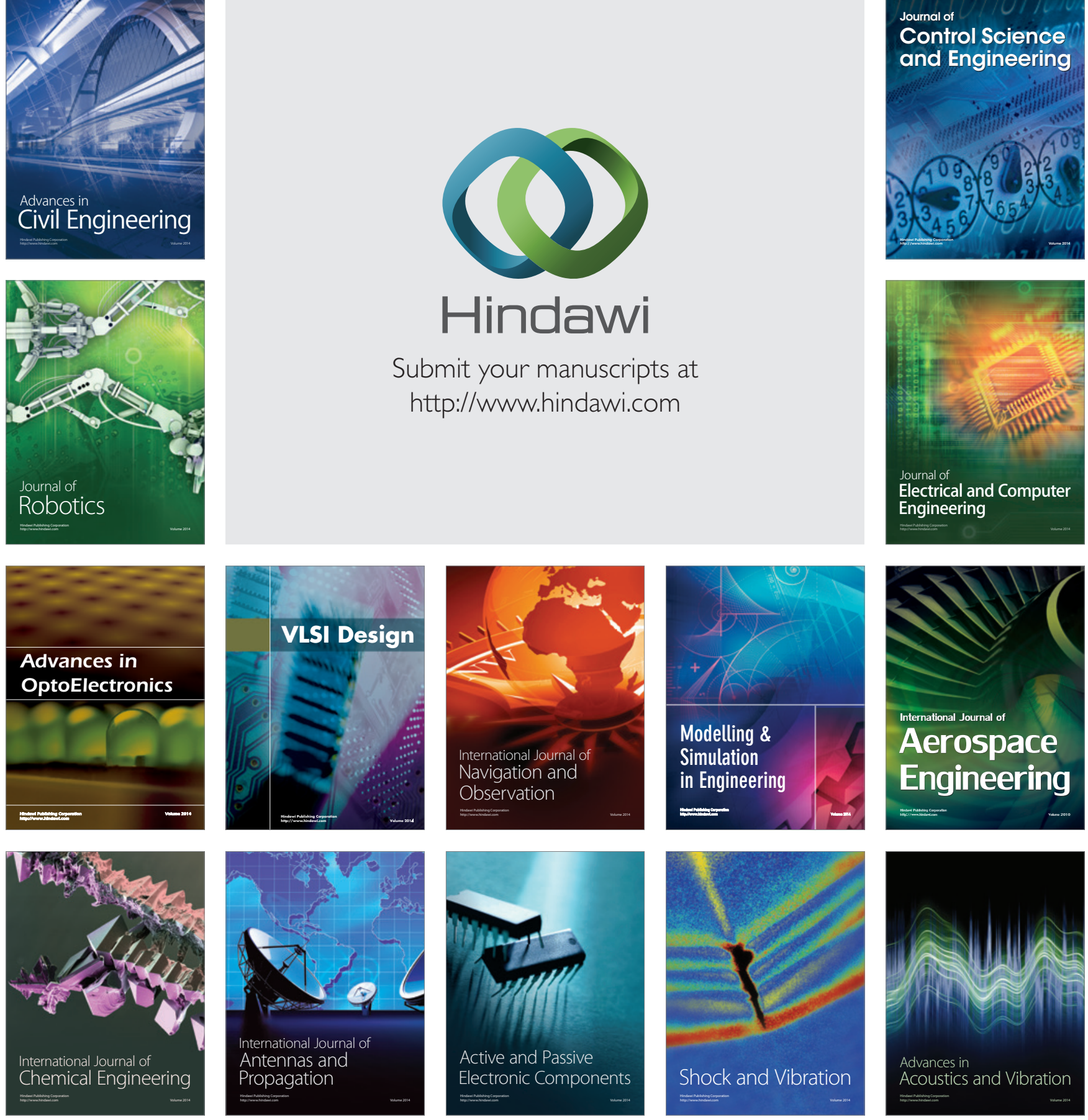